\title{
Spatial variability in bacterioplankton community composition at the Skagerrak-Kattegat Front
}

\author{
Jarone Pinhassi ${ }^{1, *}$, Anne Winding ${ }^{2}$, Svend J. Binnerup ${ }^{2}$, Ulla Li Zweifel ${ }^{4}$, \\ Bo Riemann ${ }^{3}$, Åke Hagström ${ }^{4}$

\begin{abstract}
${ }^{1}$ Institut de Ciències del Mar-CMIMA (CSIC), Passeig Marítim de la Barceloneta 37-49, 08003 Barcelona, Catalunya, Spain ${ }^{2}$ Department of Environmental Chemistry and Microbiology, and ${ }^{3}$ Department of Marine Ecology, National Environmental Research Institute, Frederiksborgvej 399, 4000 Roskilde, Denmark

${ }^{4}$ Marine Microbiology, Kalmar University, PO Box 905, 39182 Kalmar, Sweden
\end{abstract}

\begin{abstract}
The distribution of bacterial heterotrophic production and cell concentrations in the world oceans is well documented. Nevertheless, information on the distribution of specific bacterial taxa and how this is influenced by environmental factors in separate sea areas is sparse. Here we report on bacterial community structure across the Skagerrak-Kattegat front. The front separates North Sea water from water with a Baltic Sea origin. We documented community differences across the front using denaturing gradient gel electrophoresis (DGGE) analysis of PCR-amplified bacterial $16 \mathrm{~S}$ ribosomal DNA and whole-genome DNA hybridization towards community DNA. Analysis of the community 'fingerprints' by DGGE revealed clustering of samples according to side of the front and depth. Consistent with these results, whole-genome DNA hybridization for 28 bacterial species isolated from the sampling region indicated that bacteria related to the Roseobacter clade and Bacteroidetes as well as prosthecate bacteria (e.g. Hyphomonas) showed distinct distribution patterns on each side of the front, and also with depth. Differences in bacterioplankton species composition across the frontal area were paralleled by differences in quantitative variables such as phytoplankton biomass ( $\mathrm{chl}$ a), dissolved organic carbon, and bacterial production. Furthermore, we observed differences in more descriptive variables such as salinity range, bacterial growth-limiting nutrients and phytoplankton composition. We suggest that not only quantitative but also qualitative differences in variables that affect bacterial growth are required to cause divergence in bacterioplankton community composition between marine regions.
\end{abstract}

KEY WORDS: Marine bacteria $\cdot$ Plankton $\cdot$ Species distribution $\cdot$ Environmental factors $\cdot$ Denaturing gradient gel electrophoresis $\cdot$ DGGE $\cdot$ DNA hybridization

Resale or republication not permitted without written consent of the publisher

\section{INTRODUCTION}

Bacterial abundance and activity in the sea have been intensively studied for more than 3 decades. This has resulted in a substantial knowledge of bulk properties of planktonic bacteria and an appreciation of their central role in the turnover of organic matter and inorganic nutrients. However, information about the spatial distribution of specific bacterioplankton started to accumulate only in the last decade.

Studies from a variety of aquatic environments have established the concept of differential distributions of various microorganisms with depth (Giovannoni et al. 1996, Massana et al. 1997, Murray et al. 1998). Meanwhile, investigations of the horizontal distribution of marine bacteria have emphasized the degree of similarity of species present over large and geographically separated areas of the sea. An early study found ocean-basin scale differences in bacterial community composition (Lee \& Fuhrman 1991), suggesting that bacterioplankton differed significantly among seas. However, this conclusion was later challenged by the finding of identical or nearly identical bacterial sequences in Pacific and Atlantic waters, by analysis of 
16S ribosomal DNA (rDNA) clone libraries (Fuhrman et al. 1993, Mullins et al. 1995). Likewise, studies of the distribution of archaeal assemblages have emphasized the similarity of groups present over vast geographic distances (Murray et al. 1999). At smaller scales, studies of horizontal bacterioplankton distribution have also found similar bacteria in the same or adjacent sea areas (González \& Moran 1997, Murray et al. 1998, Riemann et al. 1999, Riemann \& Middelboe 2002). Nevertheless, a recent study by Suzuki et al. (2001) demonstrated small-scale $(\mathrm{km})$ heterogeneity in microbial assemblages in an upwelling area in Monterey Bay, highlighting the importance of hydrography for bacterioplankton community structure.

During most of the year large parts of the open ocean may be regarded as a relatively stable environment, due to the permanence of a thermocline. These regions are generally dominated by small phytoplankton adapted to low ambient nutrient concentrations (Platt et al. 1983). On the other hand, high abundance of large phytoplankton (e.g. diatoms) generally indicates nutrient input by vertical mixing of the water column, upwelling or eddies (Ryther 1969). Thus, significant differences in plankton composition over short distances are encountered in areas where water masses with different nutritional composition meet (Lovejoy et al. 2002). Although this is a well-established concept in phytoplankton ecology, corresponding knowledge of bacterioplankton distribution is largely lacking.

Frontal areas, where water masses with different properties meet, offer an opportunity to investigate the distribution of planktonic communities with different origins in a geographically limited area where the immediate impact of climate can be assumed to be similar. The Skagerrak-Kattegat front extends ca. $40 \mathrm{~km}$ in a northeasterly direction from the northern tip of Denmark towards Sweden, and is characterized by a northward surface flow of brackish water originating from the Baltic Sea, and a southward deep flow of more saline water from the Skagerrak and North Sea. The 2 layers are separated by a strong pycnocline at a depth of 10 to $20 \mathrm{~m}$ during most of the year (see Josefson \& Conley 1997 for a general description of frontal area). Elevated primary production and chl a concentrations have been recorded at the front compared to surrounding waters, presumably due to the mixing of water masses with different nutrient concentrations and alternate hydrography (Richardson 1985, Heilmann \& Richardson 1994, Josefson \& Conley 1997).

The concept of spatial variability in bacterial community structure is easily recognized. Nevertheless, the understanding of what factors that govern this variability is still developing. Large distances that separate areas with potentially contrasting bacterial growth properties directly hamper comparative studies of bac- terioplankton in separate seas. We studied the bacterioplankton composition across the Skagerrak-Kattegat front to take advantage of a predictable hydrographic feature, with previously documented ecological impacts on planktonic populations. It was hypothesized that sampling bacterial growth conditions in this area, combined with estimates of the community structure and abundance of different bacterial species, would allow interpretation of environmental variables in relation to patterns of bacterioplankton distribution.

\section{MATERIALS AND METHODS}

Seawater samples. Samples at 2 stations on each side of the Skagerrak-Kattegat front were collected between 17 and 20 July 1997. The stations in the Skagerrak (Stns S1 and S2) were separated by a distance of $35 \mathrm{~km}$ from the stations in the Kattegat (Stns K1 and K2) (Fig. 1) Samples were collected in the surface ( 3 to $10 \mathrm{~m}$ ) and chl a maximum (10 to $25 \mathrm{~m}$ ). In the deeper waters of the Skagerrak additional samples were taken well below the chl a maximum $(80 \mathrm{~m})$. Each of the 4 stations was sampled twice: at 12:00 $\mathrm{h}$ upon arrival to the station and at 08:00 $\mathrm{h}$ the following morning, with the exception of Stn S1. Stn S1 $\left(57^{\circ} 57^{\prime} \mathrm{N}\right.$, $10^{\circ} 44^{\prime}$ E) was sampled on 17 and 20 July; Stn K1 $\left(57^{\circ} 38^{\prime} \mathrm{N}, 11^{\circ} 03^{\prime} \mathrm{E}\right)$ on 17 and $18 \mathrm{July} ; \mathrm{Stn} \mathrm{K} 2$ $\left(57^{\circ} 33^{\prime} \mathrm{N}, 10^{\circ} 48^{\prime} \mathrm{E}\right)$ on 18 and $19 \mathrm{July} ; \mathrm{Stn} \mathrm{S} 2$ $\left(57^{\circ} 47^{\prime} \mathrm{N}, 10^{\circ} 30^{\prime} \mathrm{E}\right)$ on 19 and 20 July. Salinity, fluorescence, temperature, oxygen and pressure data were

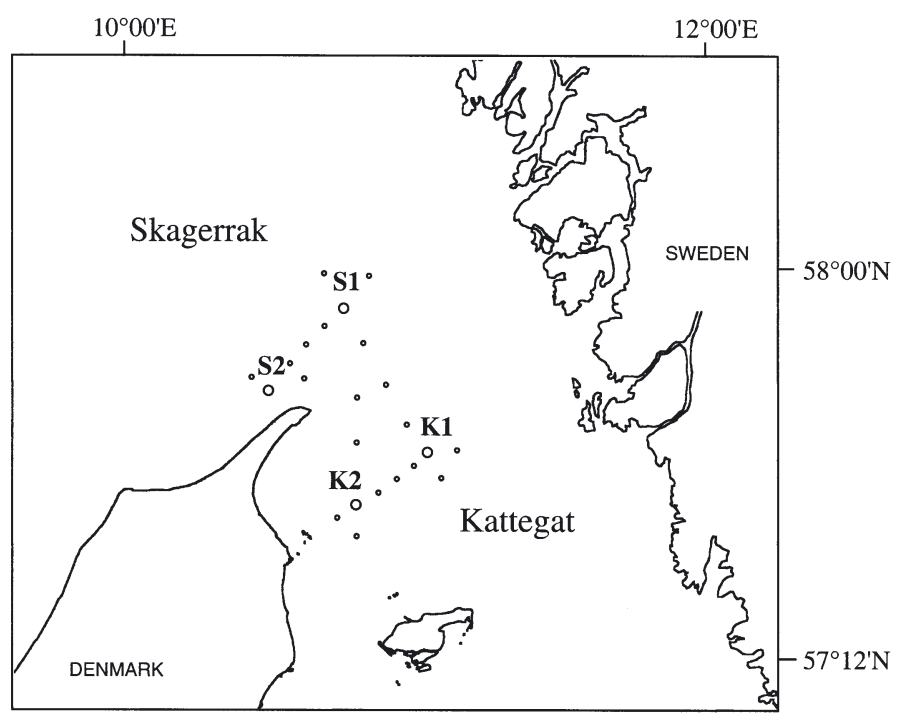

Fig. 1. Location of stations sampled at the Skagerrak-Kattegat front. Stns S1 and S2 were located in the Skagerrak, and Stns K1 and K2 in the Kattegat. Small circles indicate additional stations where CTD data were collected 
obtained with a Neil Brown Mark III CTD probe. Seawater samples were collected with a Niskin bottle rosette attached to the CTD. In addition to the main stations, CTD sampling was performed approximately every $7 \mathrm{~km}$ to determine the position of the front.

Chemical analyses. Duplicate samples of dissolved organic carbon were filtered through precombusted $13 \mathrm{~mm}$ Whatman GF/F filters, then measured using high temperature combustion with a Shimadzu TOC5000 equipped with an autosampler. Chl a concentrations were determined fluorometrically for samples collected onto Whatman GF/F filters and extracted overnight at $4{ }^{\circ} \mathrm{C}$ in $90 \%$ acetone. Phytoplankton pigment composition was analyzed by high pressure liquid chromatography (HPLC) according to the method of Wright et al. (1991), with modifications described in Schlüter \& Havskum (1997). The relative concentrations of marker pigments were obtained by relating the concentration of each marker pigment to the sum of the 8 marker pigments considered.

Bacterial production and bacterial nutrient limitation experiment. In situ bacterial production was estimated using ${ }^{3} \mathrm{H}$-thymidine incorporation (Smith \& Azam 1992). Triplicate samples and a trichloroacetic acid (TCA)killed control were incubated at in situ temperatures with $20 \mathrm{nM}^{3} \mathrm{H}$-thymidine (final concentration) for 1 to $2 \mathrm{~h}$. A conversion factor of $1.7 \times 10^{18}$ cells mol$^{-1}$ incorporated thymidine was applied. Bacterial nutrient limitation experiments were performed at Stns S1 (Skagerrak) and K1 (Kattegat). Surface seawater was divided into $500 \mathrm{ml}$ polycarbonate bottles (Nalgene) and 1 bottle was left untreated to serve as a control. One bottle was enriched with carbon ( $20 \mu \mathrm{M}$ C added as glucose), 1 bottle with nitrogen ( $2 \mu \mathrm{M}$ N added as ammonium), 1 bottle with phosphorus ( $0.2 \mu \mathrm{M}$ P added as phosphate), and 1 bottle with a combination of $\mathrm{C}, \mathrm{N}$ and $\mathrm{P}$. The treatments were subsampled after $0,3,24,48$ and $72 \mathrm{~h}$ incubation, and bacterial numbers and production were estimated. The highest response was reached after approximately $24 \mathrm{~h}$, and bacterial production was normalized to bacterial numbers from this time point to calculate the specific growth rates of the bacterial community in the different treatments.

Bacterial numbers and isolation procedure. Total counts of bacteria were determined by staining with 4', 6-diamidino-2-phenylindole (DAPI) and epifluorescence microscopy (Porter \& Feig 1980). The number of colony-forming units ( $\mathrm{CFU}$ ) was determined by plating $100 \mu \mathrm{l}$ of undiluted, $10 \times$ and $100 \times$ diluted seawater samples in triplicates onto Zobell agar plates (ZoBell 1946). Agar plates were incubated in the dark at room temperature for 10 to $15 \mathrm{~d}$. From the agar plates used for the determination of $\mathrm{CFU}$, we collected 200 isolates. Bacterial isolates were collected from all the sampling depths and times. On the basis of differences in colony morphology, 28 isolates were selected for subsequent phylogenetic identification and determination of actual abundance by whole-genome DNA hybridization. No particular screening process for isolates was employed.

Fluorescence in situ hybridization. Seawater samples were immediately filtered on $0.2 \mu \mathrm{m}$ pore-size polycarbonate filters (Poretics) and fixed overnight by placing filters on $4 \%$ freshly prepared paraformaldehyde. Bacteria were enumerated using the general eubacteria oligonucleotide probe EUB338 (Amann et al. 1990). 5'-labeled fluorescein probes were purchased from DNA Technology, and hybridization was performed as previously described (Binnerup et al. 2001). A NONEUB338 probe having a sequence complementary to EUB338 was used as a control for non-specific binding.

Denaturing gradient gel electrophoresis (DGGE). Collection of cells, DNA extraction and PCR-DGGE were done essentially as described by Christoffersen et al. (2002). In brief, $500 \mathrm{ml}$ of seawater were filtered through a $0.2 \mu \mathrm{m}$ pore-size Gelman Supor 200 filter (Gelman Sciences), and DNA was extracted from the filters by treatment with lysozyme, guadiniumthiocyanate and $\mathrm{NaI}$ and purified with QiaexII suspension and ethanol. A portion of the 16S rDNA (corresponding to position 968-1378 bp, Escherichia coli numbering) was PCR amplified by the use of the primer set F984GC (5'-[GC clamp]-AAC GCG AAG AAC CTT AC-3') (Heuer et al. 1997) and R1378 (5'-CGG TGT GTA CAA GAC CC-3') (Heuer et al. 1998) and Taq polymerase Stoffel fragment (Perkin Elmer). The PCR conditions were as follows: initially $94^{\circ} \mathrm{C}$ for $5 \mathrm{~min}$ followed by 30 cycles of $1 \mathrm{~min}$ at $95^{\circ} \mathrm{C}, 1 \mathrm{~min}$ at $53^{\circ} \mathrm{C}$, and $2 \mathrm{~min}$ at $72^{\circ} \mathrm{C}$, and finalized by $10 \mathrm{~min}$ at $72^{\circ} \mathrm{C}$. The $16 \mathrm{~S}$ rDNA fragments were separated according to GCcontent and secondary structure by DGGE run in a D GENE System (Bio-Rad) at $60^{\circ} \mathrm{C}$ for $6 \mathrm{~h}$ at $150 \mathrm{~V}$ and with a denaturing gradient of 40 to $60 \%$ (100\% denaturant agent is $7 \mathrm{M}$ urea and $40 \% \mathrm{vol} / \mathrm{vol}$ deionized formamide). The DNA was silver-stained, and the gel was photographed with a Hamamatsu CCD C5985 and digitized with the corresponding software Hamamatsu HPD-CP extended version 2.1.2 (Photonics). Similarity of the position of the 16S rDNA fragments on the DGGE gel formed the basis for a bootstrap consensus tree based on Dice similarity coefficient and the neighbor joining method, using the software Dendron ${ }^{\circledR} 3.1$ (Solltech).

Whole-genome DNA hybridization. The abundance of 28 specific bacteria was determined by wholegenome DNA hybridization towards community DNA as detailed in Pinhassi et al. (1997), where sampling procedures and sample preparation is extensively described. Briefly, the procedure was as follows. 
Community DNA samples were prepared by filtering 10 to $30 \mathrm{ml}$ of seawater onto hybridization membranes, lysing the cells with sodium hydroxide, and linking the DNA to the hybridization membranes by UV-exposure. Standard curves with a known number of cells for each species were prepared using the same protocol as for the samples. Whole-genome DNA probes were then prepared by labeling the genomic DNA prepared from each of the different bacteria with a nick translation kit (Promega) and $\left[\alpha_{-}{ }^{32} \mathrm{P}\right] \mathrm{dATP}$ (Amersham). Each probe was hybridized to triplicate community DNA samples and to the specific standard under stringent conditions for hybridization $\left(69^{\circ} \mathrm{C}\right)$ and washing $(2 \times 30 \mathrm{~min}$ washes in $2 \times$ saline sodium citrate [SSC]- $0.5 \%$ sodium dodecyl sulphate at the hybridization temperature and $2 \times 5$ min washes in $0.1 \times \mathrm{SSC}$ at room temperature [ $1 \times$ $\mathrm{SSC}$ is $0.15 \mathrm{NaCl}$ plus $0.015 \mathrm{M}$ sodium citrate]). The hybridization signal was detected and quantified using a PhosphorImager (Molecular Dynamics). The abundance of the specific bacteria was obtained by relating the hybridization signal of the samples to the hybridization signal of the standard with the known number of cells.

PCR-amplification and sequencing of isolates. 16S rDNA of the 28 bacterial isolates was amplified by means of PCR using Taq polymerase (BoehringerMannheim) from DNA preparations of cultured isolates. Bacterial 16S rDNA primers, 27f:biotinylated (AGAGTTTGATCATGGCTCAG) and 1492r (TACGGYTACCTTGTTACGACTT), were used for amplification. The reaction volumes were $50 \mu \mathrm{l}$, containing $1 \mu \mathrm{g}$ template, $10 \mathrm{mM}$ total dNTP, standard $10 \times$ Taq buffer, a total of $15 \mathrm{ng}$ of each primer, and $1 \mathrm{U}$ of Taq polymerase. The PCR amplification conditions were as fol-

Table 1. Bacterial isolates collected at the Skagerrak-Kattegat front. Related bacteria in GenBank with accession number and 16S rDNA sequence similarity are indicated. For comparison, similarity to the most similar sequence obtained from environmental 16S rDNA clone libraries is indicated. Also shown is the maximum abundance of the dominant bacteria (i.e. isolates with abundance $>1.0 \times 10^{4}$ cells $\mathrm{ml}^{-1}$ ), and the sampling station where found. ND: not detected at an abundance higher than $1.0 \times 10^{4}$ cells ml ${ }^{-1}$

\begin{tabular}{|c|c|c|c|c|c|}
\hline Isolate & $\begin{array}{c}\text { Accession } \\
\text { number }\end{array}$ & Relatives in GenBank & $\begin{array}{c}\text { Similarity } \\
(\%)\end{array}$ & $\begin{array}{l}\text { Most similar } \\
\text { clone } \\
(\%)\end{array}$ & $\begin{array}{c}\text { Sampling site } \\
\text { (abundance } \\
{\left[\times 10^{5} \mathrm{ml}^{-1}\right] \text { ) }}\end{array}$ \\
\hline \multicolumn{6}{|c|}{ Bacteroidetes } \\
\hline SKA31 & AF261053 & Flexibacter maritimus; M64629 & 95.7 & 93.7 & $\mathrm{~S} 2(0.4)$ \\
\hline SKA45 & AF261066 & Tenacibaculum sp.; AF493678 & 98.7 & 94.5 & ND \\
\hline SKA37 & AF261058 & Bacterium A16s; AF300973 & 99.8 & 97.0 & ND \\
\hline SKA38 & AF261059 & Gelidibacter algens; U62915 & 97.9 & 97.1 & ND \\
\hline SKA43 & AF261064 & Vladibacter vitellinus; AB071382 & 96.1 & 93.9 & $\mathrm{~S} 2(1.8)$ \\
\hline SKA27 & AF261049 & Microscilla sp.; AB015937 & 98.1 & 98.2 & ND \\
\hline \multicolumn{6}{|c|}{$\alpha$-proteobacteria } \\
\hline SKA26 & AF261048 & Roseobacter gallaeciensis; Y13244 & 95.4 & 95.8 & K2 (0.6) \\
\hline SKA44 & AF261065 & Roseobacter sp.; AJ244795 & 99.5 & 95.5 & $\mathrm{~K} 2(1.8)$ \\
\hline SKA24 & AF261046 & Hyphomonas oceanitis; AF082797 & 99.5 & 96.3 & $\mathrm{~S} 1$ (1.3) \\
\hline SKA25 & AF261047 & Maricaulis sp.; AJ301666 & 98.1 & 91.9 & $\mathrm{~S} 1(0.1)$ \\
\hline SKA41 & AF261062 & Brevundiminas vesicularis; AJ007801 & 99.5 & 99.3 & $\mathrm{~K} 2(1.2)$ \\
\hline SKA40 & AF261061 & Erythrobacter citreus; AF227259 & 98.6 & 99.3 & K1 (2.6) \\
\hline SKA42 & AF261063 & Porphyrobacter sanguineus; AB021493 & 96.2 & 97.9 & S1 (3.4) \\
\hline \multicolumn{6}{|c|}{$\gamma$-proteobacteria } \\
\hline SKA18 & AF261040 & Psychrobacter marincola; AJ309941 & 97.9 & 96.5 & ND \\
\hline SKA35 & AF261056 & Marinobacter hydrocarbonoclasticus; Y18240 & 99.2 & 99.4 & $\mathrm{~K} 2(0.5)$ \\
\hline SKA19 & AF261041 & Pseudoalteromonas tetraodonis; X82139 & 100 & 99.6 & $\mathrm{~K} 2(0.1)$ \\
\hline SKA20 & AF261042 & Pseudoalteromonas sp.; AF325146 & 99.8 & 96.5 & ND \\
\hline SKA32 & AF261054 & Pseudoalteromonas distincta; AF082564 & 99.8 & 99.8 & ND \\
\hline SKA29 & AF261051 & Pseudoalteromonas citrea; AF082563 & 99.8 & 96.3 & ND \\
\hline SKA22 & AF261044 & Alteromonas macleodii; Y18234 & 98.7 & 99.6 & ND \\
\hline SKA33 & AF261055 & Alteromonas macleodii; X85174 & 95.6 & 97.1 & ND \\
\hline SKA23 & AF261045 & Alteromonas macleodii; X85174 & 91.7 & 91.4 & ND \\
\hline SKA21 & AF261043 & Vibrio splendidus; X74724 & 99.1 & 99.1 & ND \\
\hline SKA28 & AF261050 & Vibrio pectenicida; Y13830 & 99.6 & 98.4 & ND \\
\hline SKA30 & AF261052 & Vibrio ordalii; X74718 & 100 & 98.5 & ND \\
\hline SKA34 & AF255623 & Photobacterium angustum; X74685 & 97.5 & 93.0 & ND \\
\hline SKA36 & AF261057 & Photobacterium phosphoreum; X74687 & 98.6 & 92.8 & $\mathrm{~K} 2(0.2)$ \\
\hline \multicolumn{6}{|c|}{ Gram-positive bacteria } \\
\hline SKA39 & AF261060 & Microbacterium kitamiense; AB013907 & 98.0 & 99.6 & ND \\
\hline
\end{tabular}


lows: 1 round of denaturation at $95^{\circ} \mathrm{C}(2 \mathrm{~min})$, annealing at $50^{\circ} \mathrm{C}(30 \mathrm{~s})$ and elongation at $72^{\circ} \mathrm{C}(45 \mathrm{~s})$ and then 29 cycles of $95^{\circ} \mathrm{C}(30 \mathrm{~s}), 50^{\circ} \mathrm{C}(30 \mathrm{~s})$ and $72^{\circ} \mathrm{C}(45 \mathrm{~s})$ using a DNA Thermal Cycler 480 (Perkin Elmer). The biotinylated strand was purified using streptavidinecoated magnetic beads (Dynabeads M280-Streptavidin, Dynal AS). A total of $25 \mu \mathrm{l}$ of Dynabeads were washed once in binding-wash buffer (Tris-EDTA + $0.1 \mathrm{M} \mathrm{NaCl}$ ), resuspended in $50 \mu \mathrm{l}$ binding-wash buffer and incubated $30 \mathrm{~min}$ with the $50 \mu \mathrm{l}$ PCR reaction at room temperature. The beads were kept in suspension by gently tapping the tubes every 2 min. The biotinylated strand was separated by denaturing 5 min with $100 \mu \mathrm{l}$ of $0.15 \mathrm{M} \mathrm{NaOH}$ and washing once with binding-wash buffer and once with water. The Dynabeads with the purified biotinylated strand were resuspended in $11 \mu \mathrm{l}$ water. The $16 \mathrm{~S}$ rDNA nucleotide sequences were determined from the purified single stranded PCR product by automated sequencing, using ABI PRISM Dye Terminator Cycle Sequencing (Perkin Elmer) with primer 518r (CGTATTACCGCGGCTGCT) (Lane et al. 1985). The 16S rDNA sequences are available at GenBank under the accession numbers AF255623 and AF261040 to AF261066 (details are given in Table 1).

\section{RESULTS}

\section{Environmental characteristics}

Salinity data were used to select 2 sampling stations on each side of the Skagerrak-Kattegat front, separated by around $35 \mathrm{~km}$ (Fig. 1). The frontal area between these stations was characterized by higher surface water salinity in the Skagerrak (30 psu), which is influenced by the North Sea, with a transition to Kattegat water (21 psu) of Baltic Sea origin. Salinity at the chl a maximum was around 34 psu in both sea areas. Water temperatures on both sides of the front were close to 19 and $13^{\circ} \mathrm{C}$ in the surface and chl a maximum, respectively, and $8^{\circ} \mathrm{C}$ was recorded in the Skagerrak deep water.

In Skagerrak, surface water dissolved organic carbon (DOC) concentrations ranged from 110 to $160 \mu \mathrm{M}$ (lowest at Stn S2), while in the Kattegat concentrations were around $180 \mu \mathrm{M}$. In the chl a maximum, DOC concentrations were lower compared to surface waters, with 90 and $125 \mu \mathrm{M}$ in the Skagerrak and Kattegat, respectively. In the Skagerrak, deep-water DOC concentrations were $65 \mu \mathrm{M}$.

$\mathrm{Chl}$ a concentrations in the surface were lower in the Skagerrak $\left(0.4 \mu \mathrm{g} \mathrm{l}^{-1}\right)$ compared to the Kattegat $(0.7 \mu \mathrm{g}$ $\mathrm{I}^{-1}$ ). Concentrations in the $\mathrm{chl}$ a maximum ranged from $1.5 \mu \mathrm{g} \mathrm{l}^{-1}$ in the Skagerrak to $3.5 \mu \mathrm{g} \mathrm{l}^{-1}$ in the Kattegat.

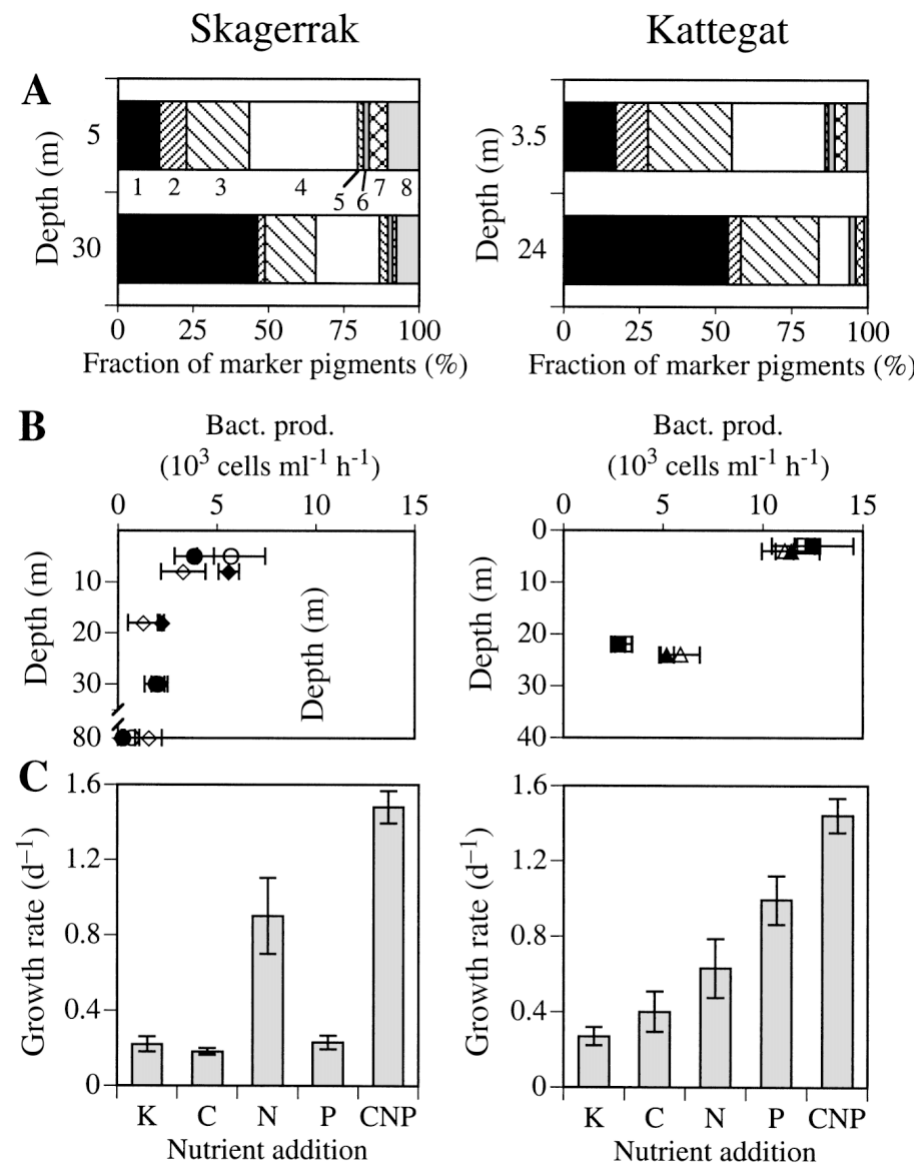

Fig. 2. Variability in phytoplankton composition and bacterial growth variables on the Skagerrak and Kattegat side of the front. (A) Relative concentration of marker pigments representing the main phytoplankton groups in the surface and chl a maximum at Stns S1 and K1. Concentrations of marker pigments were determined by HPLC. (1) Peridinin/Dinophyceae; (2) 19-butanoyloxyfucoxanthin/Pelagophyceae; (3) fucoxanthin/Diatomophyceae; (4) 19-hexanoyloxyfucoxanthin/Prymnesiophyceae; (5) prasinoxanthin/Prasinophyceae; (6) alloxanthin/Chryptophyceae; (7) zeaxanthin/Cyanophyceae; (8) chl b/ Chlorophyceae. (B) Variation in bacterial production as determined by tritiated thymidine incorporation. Samples from Stns S1 $(\mathbf{0}, \bullet)$, S2 $(\diamond, \bullet), K 1(\square, \boldsymbol{\square})$ and K2 $(\Delta, \bullet)$. Samples were taken at noon (empty symbols) and the following morning (filled symbols). (C) Changes in bacterial specific growth rates in response to addition of nutrients. Rates were calculated from bacterial production and DAPI counts of bacteria, after 26 and $21 \mathrm{~h}$ incubation of surface water at Stns S1 and K1, respectively. Labels: K: control, C: glucose, N: ammonium, P: phosphate addition. Error bars indicate standard deviations $(n=3)$

The relative concentrations of marker pigments commonly employed for chemotaxonomic interpretation are given in Fig. 2A. Peridinin, fucoxanthin and 19hexanoyloxyfucoxanthin (HFx) were the most important pigments detected in all samples. However, changes in relative contribution of pigments revealed differences in the taxonomic composition of the phytoplankton populations. Skagerrak samples had pro- 
portionally more HFx (Prymnesiophyceae) and chl $b$ (Chlorophyceae) and less fucoxanthin (Diatomophyceae) and peridinin (Dinophyceae) compared to Kattegat samples. Prasinoxanthin (Prasinophyceae) was essentially only detected in the Skagerrak. In the chl a maximum there were 3 times more peridinin and less 19-butanoyloxyfucoxanthin (Pelagophyceae) and HFx compared to the surface samples.

\section{Bacterial production and abundance}

Bacterial production rates in the surface waters differed markedly across the front, with average values of 4.6 and $11.3 \times 10^{3}$ cells ml ${ }^{-1} \mathrm{~h}^{-1}$ in the Skagerrak and Kattegat, respectively. Bacterial production in the chl a maximum was lower compared to the surface at all stations (Fig. 2B). Nutrient addition experiments with unfiltered surface seawater from Stn S1 showed that N was the only nutrient that significantly increased bacterioplankton specific growth rates when added by itself, indicating N-limitation of bacterial growth in the Skagerrak (Fig. 2C). At Stn K1, addition of P was the single nutrient added that resulted in most elevated growth rates, suggesting mainly P-limited growth of bacterioplankton in the Kattegat. At both stations the highest rates were recorded in the combined $\mathrm{C}+\mathrm{N}+\mathrm{P}$ treatments.

Total bacterial abundance (DAPI counts) mostly ranged from 0.6 to $1.0 \times 10^{6}$ cells $\mathrm{ml}^{-1}$, with occasionally higher numbers from Stn K2 samples from the Kattegat $\left(1.8 \times 10^{6}\right.$ cells ml $\left.^{-1}\right)$. From 9 to $73 \%$ (average $31 \%$ ) of the DAPI counts were accounted for using fluorescence in situ hybridization (FISH) with the general bacteria probe EUB338 labeled with fluorescein (Table 2). These proportions may be low compared to those obtained with the presently most used fluores- cent label Cy3. In fact, in the adjacent North Sea an average of $48 \%$ of the DAPI counts were detected using Cy3 labeled EUB338 probes, while recent advances demonstrate that detection rates increase to nearly $100 \%$ using FISH with tyramide signal amplification (Pernthaler et al. 2002). Using whole-genome DNA hybridization, the abundance of the 28 quantified bacteria together explained from 3 to $59 \%$ (average $25 \%$ ) of the DAPI counts. Bacteria-forming colonies on Zobell agar plates never exceeded $2.5 \times 10^{3} \mathrm{ml}^{-1}$ or $0.003 \%$ of the DAPI counts (Table 2).

\section{DGGE analysis}

DGGE of PCR-amplified 16S rDNA resolved between 8 and 21 (typically 15) bands in each sample, of which 3 were present in all community DNA samples (data not shown). Cluster analysis based on presence or absence of bands in the community fingerprints showed that Skagerrak deep-water samples formed a distinct cluster, supported by high bootstrap values (Fig. 3). The chl a maximum samples formed 2 clusters, basically separating Skagerrak from Kattegat samples, although some deviations were observed (e.g. chl a maximum sample $\mathrm{S} 1_{1}$ ). The cluster of surface samples indicated a separation between Skagerrak and Kattegat samples, although bootstrap values within this cluster were generally low.

\section{Identity of the quantified bacteria}

The phylogenetic affiliation of the 28 bacterial species quantified by whole-genome DNA hybridization is presented in Table 1. Nearly all isolates showed $>95 \%$ 16S rDNA sequence similarities to previously isolated

Table 2. Comparison of abundances of the 28 specific bacteria to bacterial numbers obtained by DAPI staining, fluorescence in situ hybridization (FISH) with the general bacteria probe EUB338, and CFU. Abundance of each of the 28 specific bacteria was obtained by whole-genome DNA hybridization to bacterial community DNA. Stn S1 was sampled at noon on 17 July 1997, and Stns K1, K2 and S2 in the mornings of 18, 19, 20 July 1997, respectively. ND: not determined

\begin{tabular}{|c|c|c|c|c|c|c|c|}
\hline \multirow[t]{2}{*}{ Sea area } & \multirow[t]{2}{*}{ Stn } & \multirow{2}{*}{$\begin{array}{l}\text { Sampling date } \\
\text { (1997) }\end{array}$} & \multirow[t]{2}{*}{ Depth } & \multicolumn{3}{|c|}{ Bacterial numbers $\left(\times 10^{5}\right.$ cells ml $\left.{ }^{-1}\right)$} & \multirow{2}{*}{$\begin{array}{c}\mathrm{CFU} \\
\left(\times 10^{3} \mathrm{ml}^{-1}\right)\end{array}$} \\
\hline & & & & $\begin{array}{l}\text { DAPI } \\
\text { counts }\end{array}$ & $\begin{array}{l}28 \text { specific bacteria } \\
\text { (\% of DAPI counts) }\end{array}$ & EUB338 & \\
\hline \multirow[t]{2}{*}{ Skagerrak } & \multirow[t]{2}{*}{ S1 } & \multirow[t]{2}{*}{$17 \mathrm{Jul}$} & Surface & $6.00 \pm 0.71$ & $0.82 \pm 0.08(14)$ & ND & $0.48 \pm 0.07$ \\
\hline & & & Chl max & $7.91 \pm 0.30$ & $0.64 \pm 0.05(8)$ & ND & $0.84 \pm 0.03$ \\
\hline \multirow[t]{2}{*}{ Skagerrak } & \multirow[t]{2}{*}{$\mathrm{S} 2$} & \multirow[t]{2}{*}{$20 \mathrm{Jul}$} & Surface & $6.52 \pm 0.39$ & $2.94 \pm 0.54(45)$ & $4.74 \pm 0.23$ & $2.21 \pm 0.18$ \\
\hline & & & Chl max & $6.44 \pm 0.18$ & $1.53 \pm 0.22(24)$ & $2.82 \pm 0.09$ & $0.63 \pm 0.11$ \\
\hline \multirow[t]{2}{*}{ Kattegat } & \multirow[t]{2}{*}{ K1 } & \multirow[t]{2}{*}{$18 \mathrm{Jul}$} & Surface & $8.07 \pm 0.41$ & $1.20 \pm 0.20(15)$ & $1.27 \pm 0.18$ & $1.19 \pm 0.13$ \\
\hline & & & Chl max & $6.67 \pm 0.50$ & $2.68 \pm 0.38(4)$ & ND & $1.77 \pm 0.23$ \\
\hline \multirow[t]{2}{*}{ Kattegat } & \multirow[t]{2}{*}{$\mathrm{K} 2$} & \multirow[t]{2}{*}{$19 \mathrm{Jul}$} & Surface & $9.03 \pm 0.32$ & $0.68 \pm 0.16(7)$ & $0.85 \pm 0.11$ & $1.07 \pm 0.06$ \\
\hline & & & Chl max & $10.09 \pm 0.38$ & $0.30 \pm 0.05$ & $1.44 \pm 0.18$ & $0.83 \pm 0.12$ \\
\hline
\end{tabular}




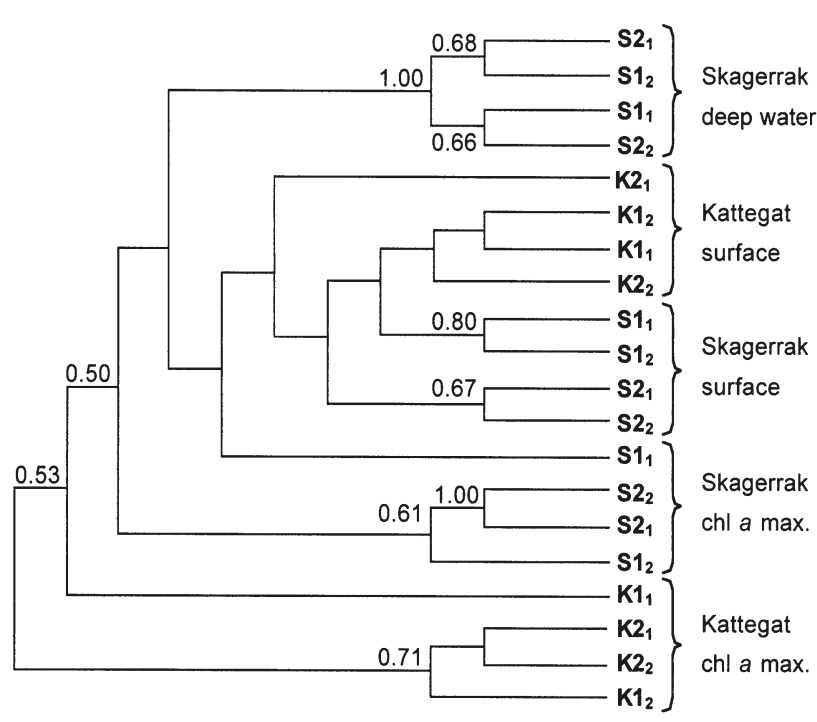

Fig. 3. Dendrogram comparing DGGE fingerprints of the bacterial communities at all stations and depths sampled. Bootstrap values larger than $50 \%$ are indicated at the branches. Codes at the end of the branches indicate station sampled, with subscripts representing (1) noon sample and (2) sample collected the following morning

bacteria. Likewise, 21 of the isolates showed >95\% sequence similarities to sequences obtained from $16 \mathrm{~S}$ rDNA clone libraries. A total of 6 isolates showed higher sequence similarities to cloned sequences compared to previously isolated strains. This suggests that the bacterial diversity reported from clone libraries now also covers a grand portion of the bacteria found in culture.

A substantial portion of the bacterial community was accounted for by 7 species of $\alpha$-proteobacteria, i.e. bacteria in the Roseobacter group, prosthecate bacteria (e.g. Hyphomonas, Brevundimonas and Maricaulis), and Sphingomonadaceae (e.g. Erythrobacter and Porphyrobacter). The latter 2 genera, although not regularly found in open ocean environments, harbor several species that contain bacteriochlorophyll a (Shiba \& Simidu 1982, Fuerst et al. 1993), which may aid in satisfying their energy demand. Among the Bacteroidetes, 2 out of 6 isolated species were found to be abundant. A total of 14 different isolates belonged to the $\gamma$-proteobacteria, of which only 3 were abundant (none above $5.0 \times 10^{4}$ cells $\mathrm{ml}^{-1}$ ). One gram-positive isolate was found.

\section{Whole-genome DNA hybridization results}

When depicted across the front, there was a clear difference in bacterioplankton species distribution.
Twelve of the quantified bacteria were detected at $>1.0 \times 10^{4}$ cells $\mathrm{ml}^{-1}$, and were thus considered important plankton members at the time of sampling. Four species were exclusively abundant in the Skagerrak (Fig. 4A), while 4 others were restricted to the Kattegat (Fig. 4B). In addition, a group of bacteria was widely distributed across the front (Fig. 5).

In the Skagerrak, the specific bacterioplankton detected included Vladibacter sp. (SKA43), Нyphomonas oceanitis (SKA24), Porphyrobacter sp. (SKA42) and Maricaulis sp. (SKA25). These bacteria showed peak abundances up to $3.4 \times 10^{5} \mathrm{ml}^{-1}$ (Fig. 4A). Vladibacter sp. and $H$. oceanitis were most abundant in the surface, and the latter was also abundant in the chl a maximum. Porphyrobacter sp. was mainly associated with the chl a maximum.

In the Kattegat, Erythrobacter sp. (SKA40) was most abundant in the chl a maximum at Stn K1 (as many as $2.6 \times 10^{5}$ cells ml $^{-1}$ ), and was only found in low numbers at the other stations (Fig. 4B). Roseobacter sp. (SKA26), Marinobacter hydrocarbonoclasticus (SKA35), and Photobacterium phosphoreum (SKA36) were restricted to Kattegat surface waters and showed peaks in abundance at Stn K2 on 18 July 1997.

Several of the species that were abundant in the surface at Stn K2 in the Kattegat at noon on 18 July 1997 were much less abundant the following morning (Fig. 4B). The DGGE analysis also indicated that the composition of the bacterioplankton had shifted over night, i.e. the divergent positions of the 2 samples from Stn K2 (Fig. 3). These changes were observed in conjunction with a decrease in DAPI counts from

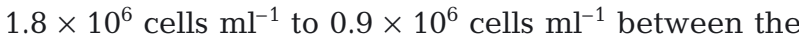
2 sampling occasions, despite little change in hydrography. No corresponding changes were found at the chl a maximum, suggesting that a surface water parcel had been replaced during the night.

Both Roseobacter sp. (SKA44) and Brevundimonas vesicularis (SKA41) showed major peaks in abundance in the surface waters at Stn K2. These 2 species were also abundant at Stns K1 and S2, although at different depths (Fig. 5). Flexibacter sp. (SKA31) was more variable, with abundance peaks at different depths and stations.

\section{DISCUSSION}

\section{Spatial variability in marine bacterioplankton}

The spatial distribution of bacterioplankton across the Skagerrak-Kattegat front was investigated by means of whole-genome DNA hybridization as well as DGGE. Both methods independently indicated differences in bacterial community composition on a hori- 

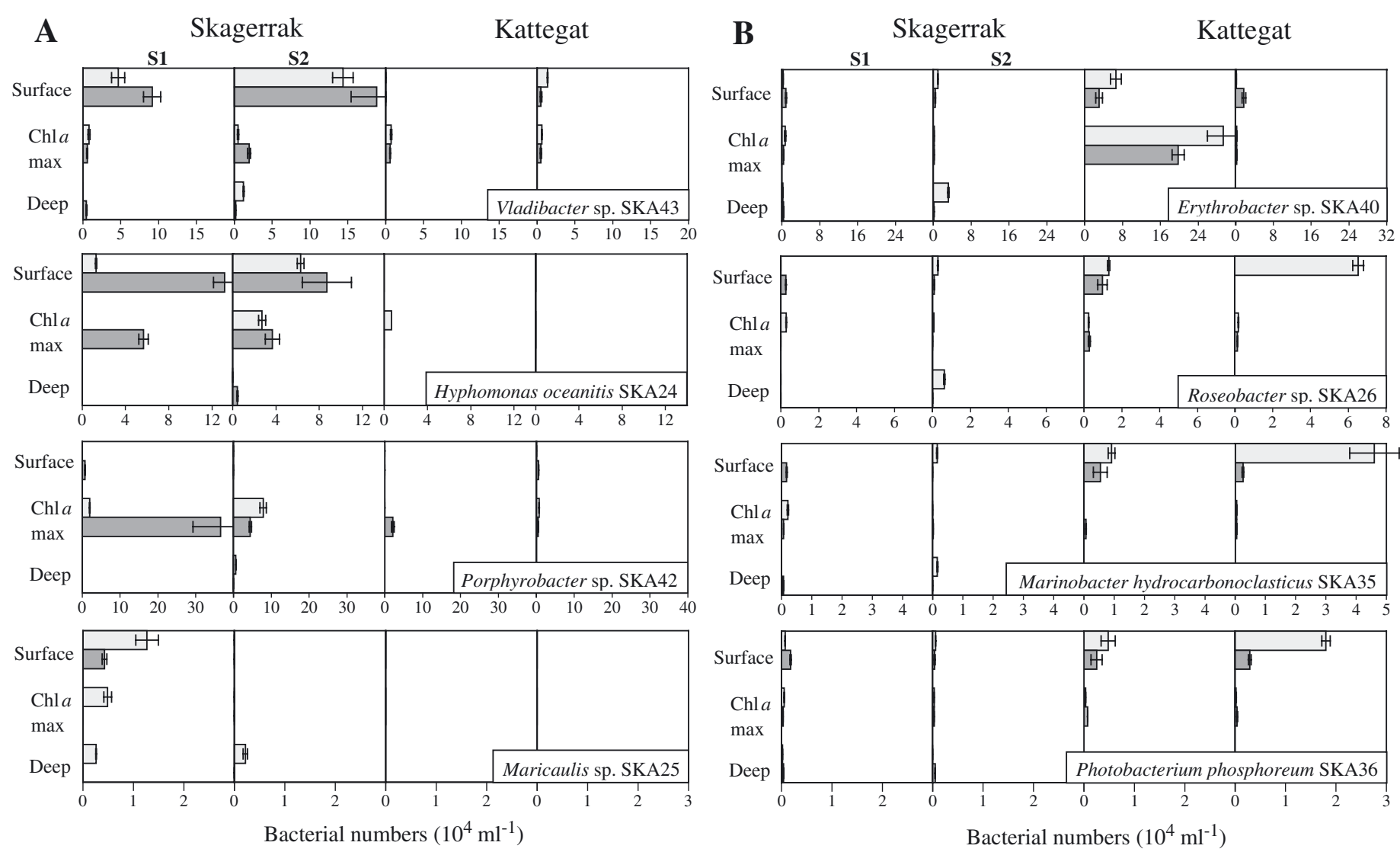

Fig. 4. Spatial distribution of numerically abundant marine bacteria that occur mainly on the Skagerrak (A) and Kattegat (B) side of the front. Light and dark grey columns indicate noon and morning samples, respectively. Abundance of specific bacteria was determined by wholegenome hybridization. Error bars indicate standard deviations $(n=3)$

zontal scale over a distance of only $35 \mathrm{~km}$. Furthermore, clear differences in species distribution with depth were evident. This spatial variability coincided with the existence of the front, which divided 2 distinct water-masses within a limited area. These watermasses showed distinct characteristics in terms of salinity, DOC and chl a concentrations, phytoplankton marker pigments and bacterial production. We also found evidence for different limiting nutrients for bacterial growth in the 2 regions.

The majority of studies in marine environments have demonstrated the similarity of bacterioplankton composition over large geographic areas (Fuhrman et al. 1993, Mullins et al. 1995). For example, using DGGE analysis, Riemann et al. (1999) found that the bacterioplankton community in the Arabian Sea was dominated by the same 15 phylotypes, despite apparent variability in productivity, chl a concentrations and bacterial abundance in the surface mixed layer. These common phylotypes included cyanobacteria and $\alpha$ and $\delta$-proteobacteria at stations as far as $1500 \mathrm{~km}$ apart (Riemann et al. 1999). More recently, Riemann \& Middelboe (2002) found a stable bacterial community in Danish coastal waters, despite ample variability in productivity. To explain these observations the authors suggested that wide phenotypic plasticity in bacterial physiology would enable a few bacterial phylotypes/ species to have a widespread distribution (Riemann \& Middelboe 2002, Riemann et al. 1999).

However, there exist a few studies suggesting that not only variability with depth, but also horizontal variability in bacterioplankton species composition in the sea may exist over short distances, particularly in upwelling areas and frontal zones (Kerkhof et al. 1999, Suzuki et al. 2001, Zubkov et al. 2002). Suzuki et al. (2001) conducted a high-resolution study of the spatial distribution on bacterial groups across an upwelling plume in the Monterey Bay, and found that the abundance of bacteria in the Cytophagales, SAR86 and Roseobacter groups varied in relation to salinity, chl a concentration and distance from shore over distances of 5 to $25 \mathrm{~km}$. Analysis of the same bacterial groups in the North Sea revealed patchiness on a scale of 10 to $100 \mathrm{~km}$, although no relationship with environmental variables was found (Zubkov et al. 2002). More pronounced differences in bacterioplankton community 

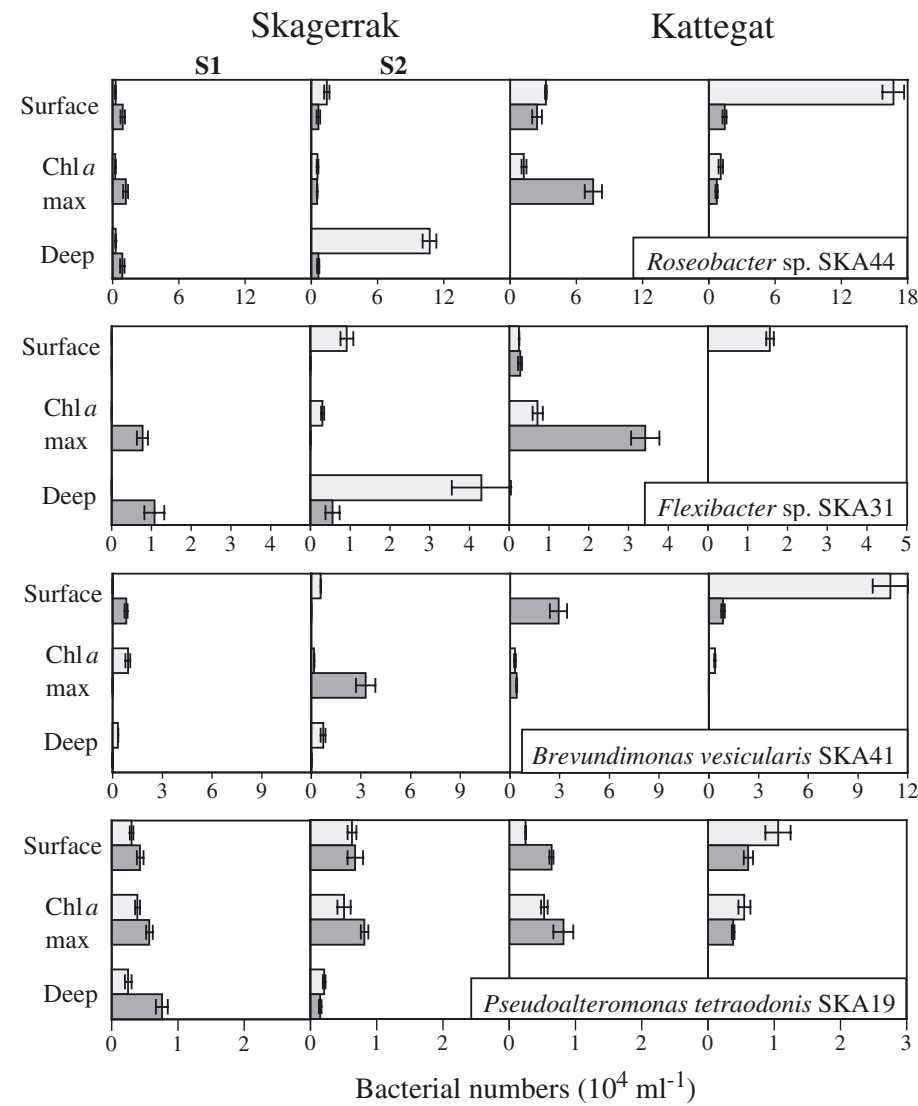

Fig. 5. Spatial distribution of bacteria with a variable occurrence on both sides of the Skagerrak-Kattegat front. Other figure details same as in Fig. 4

composition have been demonstrated in comparative studies in estuarine/coastal environments or neighboring lakes, depending on differences, for example, in trophic status, turbidity, and freshwater inflow (Murray et al. 1996, Lindström 2000, Schauer et al. 2000). How then is it possible to reconcile that over large sea areas bacterioplankton composition is the same despite seemingly important variability in, e.g., chl a concentrations, while in other locations a similar variability in chl a concentrations results in different bacterial communities?

\section{Mechanisms behind differences in community composition}

One explanation to the above paradox could be that in addition to quantitative differences in environmental variables that affect bacterial growth, qualitative differences might also be important to trigger variability in bacterioplankton community composition. In the present study differences in variables that are important descriptors of aquatic ecosystems, such as chl a and DOC concentrations and bacterial heterotrophic production, were found across the Skagerrak-Kattegat frontal area. However, as indicated by, for example, the Arabian Sea study cited above (Riemann et al. 1999), differences in these variables alone might not be sufficient to cause detectable differences in bacterioplankton species distribution. Therefore, in the current context descriptive variables that indicate differences in growth conditions of a more qualitative character across the front may be important. These included salinity range, phytoplankton species composition and limiting nutrients for bacterial growth.

Salinity is an important regulating factor that determines the possibility of bacteria as well as higher organisms to grow in certain environments, and there is evidence of pronounced differences in bacterial species composition between freshwater and marine environments (Glöckner et al. 2000). For example, Gonzalez \& Moran (1997) found a similar distribution of $\alpha$-proteobacteria related to the genus Roseobacter in 3 estuaries across the southeastern USA, while their abundance in each estuary declined predictably with salinity.

Marker pigment analyses indicated that, in addition to differences in chl a concentrations between Skagerrak and Kattegat samples, variability in phytoplankton composition existed across the front, as well as with depth. This variability could be caused by underlying factors such as nutrient availability and mixing regimes, which also act selectively on bacterioplankton. But it is also plausible that the distribution of some bacterioplankton species depend on specific associations with phytoplankton. Interestingly, phytoplankton culture studies have found a substantial degree of specificity between particular bacteria and algae (Hold et al. 2001, Schäfer et al. 2002). One explanation for this association is that different algae might provide qualitatively different DOC, and thereby selectively affect bacterial growth. However, the occurrence of a specific association between particular assemblages of algae and bacteria remains to be demonstrated in situ.

As in the present study, differences in bacterial growth limitation by availability of inorganic nutrients or carbon in different areas of the sea have been demonstrated (Cotner et al. 1997, Kirchman 1990). Similarly, nutrient limitation may vary with depth (Sala et al. 2002). However, we are aware of no studies that have directly investigated the role of nutrient limitation on bacterial community structure. In addition, there are few data on the preference of specific bacteria for particular nutrients or substrates in an ecological context (Pernthaler et al. 2001, Kisand et al. 2002, Pinhassi \& Berman 2003). Vrede et al. (2002) recently demonstrated that macromolecular composition and 
size of bacteria varies greatly depending on which nutrient limits their growth. Furthermore, Pernthaler et al. (2001) showed that the rate of substrate supply could determine the outcome of competition experiments between 2 species of $\gamma$-proteobacteria. Together, these observations strongly suggest that variability in the type and magnitude of nutrient limitation could be a selective force in structuring bacterioplankton composition.

\section{Considerations of the whole-genome DNA hybridization protocol}

The distribution of bacteria shown in Figs. 4 \& 5 was obtained by quantitative whole-genome DNA hybridization towards community DNA. The issue of specificity of the hybridization protocol has been previously discussed in depth (Pinhassi et al. 1997, Kisand et al. 2002), but some actual comments may be warranted. We did not specifically determine the level of cross hybridization between the present isolates. We have demonstrated that cross hybridization signals rapidly decline from $100 \%$ between identical isolates to $25 \%$ or much less when $16 \mathrm{~S}$ rDNA sequence similarity is less than $97 \%$ (Hagström et al. 2000). In most cases the 16S rDNA sequence similarities among isolates in this study were much lower than $97 \%$. A conservative estimate would be that in total, crosshybridization between the probes used could have resulted in an overestimation in the range of 10 to $20 \%$ of the abundance of the targeted bacteria.

Another concern is that the abundance of target organisms (i.e. those which the whole-genome probes aim to detect) could be severely overestimated if nontarget organisms (e.g. uncultured relatives of the cultured species) with significant cross-hybridization to the target organisms are very abundant. Consider the following example:

Assume that a target organism in the water column is as abundant as 10 non-target organisms. The nontarget organisms each have a $16 \mathrm{~S}$ rDNA sequence similarity of approximately 96 to $97 \%$ to the target organism, and therefore each add at least $10 \%$ to the hybridization signal of the target organism. This could then result in an unspecific hybridization signal that is as high as the signal from the target organism itself. In this scenario unspecific hybridization could even lead to the detection of the target organism although the target organism itself is absent from the water column. Moreover, a cross-hybridization level of $10 \%$ with a single non-target species that is 100 times more abundant than the target organism would result in a 10-fold overestimation of the target organism in the water column.
We could now apply this line of reasoning to our hybridization data collected at the SkagerrakKattegat front. Here we detected, for example, Hyphomonas oceanitis (SKA24) at an abundance of $1.3 \times 10^{5}$ cells $\mathrm{ml}^{-1}$ at Stn S1. To produce an unspecific hybridization signal corresponding to this abundance from non-target species with a level of cross hybridization of, let's say, $20 \%$ to the target species, the nontarget species would have to have been present at an abundance of $6.5 \times 10^{5}$ cells $\mathrm{ml}^{-1}$ in the water column. This is similar to the total number of cells ml ${ }^{-1}$ at this station, $6.0 \times 10^{5} \mathrm{ml}^{-1}$, as determined by DAPI staining, suggesting that the bacterial community sampled would nearly have been a mono-culture. Considering that all our quantified bacteria at this station were detected at a total abundance of $0.82 \times 10^{6}$ cells ml $^{-1}$, it would require $4.1 \times 10^{6}$ non-target organisms $\mathrm{ml}^{-1}$ nearly 7 times more than the actual DAPI counts-to account for the detected hybridization signal. Thus, rather than yielding hybridization signals based on unspecific binding of the probe to various unknown plankton members, we find it conceivable that the present whole-genome DNA hybridization protocol conferred sufficient resolution to provide a description of some abundant taxa at the time of sampling.

\section{Distribution of bacteria in relation to life history traits}

Many novel bacterioplankton species have been discovered in marine environments over the last decade (Giovannoni et al. 1990, Fuhrman et al. 1993, Hagström et al. 2000), yet there is limited knowledge of the distribution, growth requirements and performance of these bacteria in the sea, although some information on their ecology is beginning to accumulate (Weinbauer \& Höfle 1998, Pernthaler et al. 2001, Pinhassi and Berman 2003). Only in a few cases has the dominance of a particular bacterial species been directly explained by its physical, chemical and biological surrounding. Nevertheless, in the following text we have tried to gather information on properties that could contribute to understanding the factors that influence the abundance of some bacteria in the present study.

The studied $\alpha$-proteobacteria were phylogenetically diverse, with representatives from the Roseobacter clade, Sphingomonadaceae, Caulobacteraceae, and the Hyphomonas group, and several of them were detected in high abundance. Results from recent dilution culture experiments have suggested that these bacteria are most competitive at low ambient substrate and nutrient concentrations (Pinhassi \& Berman 2003). Bacteria in the Roseobacter clade are widespread in the oceans, and in the North Sea they have been found 
to be most abundant in summer (Eilers et al. 2000). Correspondingly, in the northern Baltic Sea Sphingomonas and Caulobacter species were found to be dominant during stratified summer conditions (Pinhassi \& Hagström 2000). Prosthecate bacteria, which historically were largely united in the genus Caulobacter based on their morphology, are known for their capacity to grow at low ambient substrate and nutrient concentrations. Detailed phylogenetic analyses have suggested a separation of the 'caulobacters' into 3 genera with distinct salt requirements (Abraham et al. 1999). The genus Caulobacter is retained for the freshwater species, while salt-tolerant species are united in the genus Brevundimonas. Truly marine species with a salt requirement for growth form the genus Maricaulis, which is more closely related to bacteria in the genus Hyphomonas than to Caulobacter (Abraham et al. 1999). In line with the basic growth requirements of these genera we found that $B$. vesicularis reached high abundance in the less saline Kattegat, while a Maricaulis sp. was detected in the Skagerrak.

Hyphomonas species typically catabolize protein and amino acids for energy and growth (Weiner et al. 2000), and the high abundance of $H$. oceanitis in the Skagerrak could be due to an ability to utilize these substrates in an otherwise nitrogen-limited environment. Also Vladibacter sp. (Bacteroidetes) was restricted to the Skagerrak. In mesocosm experiments Cytophaga relatives achieved rapid growth by exploiting temporarily increased protein concentrations (Pinhassi et al. 1999). Consistently, Cottrell \& Kirchman (2000) have found that Cytophaga relatives have a high capacity for protein utilization compared to other bacterial groups. Thus, these bacteria may be important scavengers of patches of protein at the frontal area.

We identified a variety of $\gamma$-proteobacteria in our samples, most of which made up only a small proportion of the community DNA at the frontal system. However, some physiological and ecological features known for Alteromonas macleodii render it as being of some interest. A commonly isolated marine bacterium with a widespread distribution (Hagström et al. 2000), A. macleodii dominated the particle-attached bacterial community throughout the water column in the NW Mediterranean (Acinas et al. 1999). It is possible that Alteromonas species may be involved in particle processing also at the Skagerrak-Kattegat front.

The Skagerrak-Kattegat front is a meeting point between North Sea and Baltic Sea water, and as such provides an interesting area for the study of microbial population ecology. In this area, within a short distance, 2 distinct marine habitats are maintained, and between them we found different bacterioplankton species to be distributed. Here we have hinted upon the possibility that differences in bacterioplankton composition between marine areas may result from qualitative differences in bacterial growth conditions, in addition to the recognized importance of quantitative differences. With the advancing skills in culturing marine bacteria (Connon \& Giovannoni 2002) and the modern molecular biology tools now at hand (Eilers et al. 2001, Suzuki et al. 2001, Lebaron et al. 2002), the issue of describing factors that select for specific marine bacteria can be tackled in the near future.

Acknowledgements. The officers and crew of the Danish Fisheries Institute RV 'DANA' made the cruise easy to perform and a pleasant experience. M. Søndergaard is thankfully acknowledged for contributing to the success of the cruise and for providing DOC data. The technical assistance of W. Martinsen and $\mathrm{T}$. Thane is acknowledged. The invaluable comments by C. Lovejoy improved the manuscript. We are grateful for the helpful criticism of an earlier version of the manuscript by Pep Gasol and K. van Lenning. The constructive comments by reviewers on past and present versions markedly improved the manuscript. This project was supported by the Danish and Swedish research councils grants 9601319, 9701015 and B65019981070; and by a postdoc fellowship grant from The Swedish Foundation for International Cooperation in Research and Higher Education (STINT) to J.P.

\section{LITERATURE CITED}

Abraham WR, Strömpl C, Meyer H, Lindholst S and 7 others (1999) Phylogeny and polyphasic taxonomy of Caulobacter species: proposal of Maricaulis gen. nov. with Maricaulis maris (Poindexter) comb. nov. as the type species, and emended description of the genera Brevundimonas and Caulobacter. Int J Syst Bacteriol 49:1053-1073

Acinas SG, Antón J, Rodríguez-Valera F (1999) Diversity of free-living and attached bacteria in offshore western Mediterranean waters as depicted by analysis of genes encoding 16S rRNA. Appl Environ Microbiol 65:514-522

Amann RI, Krumholz L, Stahl DA (1990) Fluorescent-oligonucleotide probing of whole cells for determinative, phylogenetic, and environmental studies in microbiology. J Bacteriol 172:762-770

Binnerup SJ, Bloem J, Hansen BM, Wolters W, Veninga M, Hansen M (2001) Ribosomal RNA content in microcolony forming soil bacteria measured by quantitative 16S rRNA hybridization and image analysis. FEMS Microbiol Ecol $37: 231-237$

Christoffersen K, Lyck S, Winding A (2002) Microbial activity and bacterial community structure during degradation of microcystins. Aquat Microb Ecol 27:125-136

Connon SA, Giovannoni SJ (2002) High-throughput methods for culturing microorganisms in very-low-nutrient media yield diverse new marine isolates. Appl Environ Microbiol 68:3878-3885

Cotner JB, Ammerman JW, Peele ER, Bentzen E (1997) Phosphorus-limited bacterioplankton growth in the Sargasso Sea. Aquat Microb Ecol 13:141-149

Cottrell MT, Kirchman DL (2000) Natural assemblages of marine Proteobacteria and members of the CytophagaFlavobacter cluster consuming low- and high-molecularweight dissolved organic matter. Appl Environ Microbiol 66:1692-1697 
Eilers H, Pernthaler J, Glöckner FO, Amann R (2000) Culturability and in situ abundance of pelagic bacteria from the North Sea. Appl Environ Microbiol 66:3044-3051

Eilers H, Pernthaler J, Peplies J, Glöckner FO, Gerdts G, Amann R (2001) Isolation of novel pelagic bacteria from the German Bight and their seasonal contributions to surface picoplankton. Appl Environ Microbiol 67:5134-5142

Fuerst JA, Hawkins JA, Holmes A, Sly LI, Moore CJ, Stackebrandt E (1993) Porphyrobacter neustonensis gen. nov., sp. nov., an aerobic bacteriochlorophyll-synthesizing budding bacterium from fresh water. Int J Syst Bacteriol 43: 125-134

Fuhrman JA, McCallum K, Davis AA (1993) Phylogenetic diversity of subsurface marine microbial communities from the Atlantic and Pacific oceans. Appl Environ Microbiol 59:1294-1302

Giovannoni SJ, Britschgi TB, Moyer CL, Field KJ (1990) Genetic diversity in Sargasso Sea bacterioplankton. Nature 345:60-63

Giovannoni SJ, Rappé MS, Vergin KL, Adair NL (1996) 16S rRNA genes reveal stratified open ocean bacterioplankton populations related to the Green Non-Sulfur bacteria. Proc Natl Acad Sci USA 93:7979-7984

Glöckner FO, Zaichikov E, Belkova N, Denissova L, Pernthaler J, Pernthaler A, Amann R (2000) Comparative 16S rRNA analysis of lake bacterioplankton reveals globally distributed phylogenetic clusters including an abundant group of Actinobacteria. Appl Environ Microbiol 66: 5053-5065

González JM, Moran MA (1997) Numerical dominance of a group of marine bacteria in the alpha-subclass of the class Proteobacteria in coastal seawater. Appl Environ Microbiol 63:4237-4242

Hagström Å, Pinhassi J, Zweifel UL (2000) Biogeographical diversity among marine bacterioplankton. Aquat Microb Ecol 21:231-244

Heilmann JP, Richardson K (1994) Annual distribution and activity of phytoplankton in the Skagerrak/Kattegat frontal region. Mar Ecol Prog Ser 112:213-223

Heuer H, Krsek M, Baker P, Smalla K, Wellington EMH (1997) Analysis of actinomycete communities by specific amplification of genes encoding 16S rRNA and gelelectrophoretic separation in denaturing gradients. Appl Environ Microbiol 63:3233-3241

Heuer H, Engelen B, Smalla K (1998) Application of temperature gradient gel electrophoresis (TGGE) to study microbial communities. Workshop on Genetic Fingerprinting of Microbial Communities - present status and future perspectives. Max-Planck-Institute for Marine Microbiology, Bremen

Hold GL, Smith EA, Rappé MS, Maas EW and 6 others (2001) Characterization of bacterial communities associated with toxic and non-toxic dinoflagellates. FEMS Microbiol Ecol 37:161-173

Josefson AB, Conley DJ (1997) Benthic response to a pelagic front. Mar Ecol Prog Ser 147:49-62

Kerkhof LJ, Voytek MA, Sherrell RM, Millie D, Schofield O (1999) Variability in bacterial community structure during upwelling in the coastal ocean. Hydrobiologia 401: 139-148

Kirchman DL (1990) Limitation of bacterial growth by dissolved organic matter in the subarctic Pacific. Mar Ecol Prog Ser 62:47-54

Kisand V, Cuadros R, Wikner J (2002) Phylogeny of culturable estuarine bacteria catabolizing riverine organic matter in the northern Baltic Sea. Appl Environ Microbiol 68: $379-388$
Lane DL, Pace B, Olsen GJ, Stahl DA, Sorgin ML, Pace NR (1985) Rapid determination of 16S rRNA sequences for phylogenetic analysis. Proc Natl Acad Sci USA 82: 6955-6959

Lebaron P, Servais P, Baudoux AC, Bourrain M, Courties C, Parthuisot N (2002) Variations of bacterial-specific activity with cell size and nucleic acid content assessed by flow cytometry. Aquat Microb Ecol 28:131-140

Lee S, Fuhrman JA (1991) Spatial and temporal variation of natural bacterioplankton assemblages studied by total genomic DNA cross-hybridization. Limnol Oceanogr 36: $1277-1287$

Lindström ES (2000) Bacterioplankton community composition in five lakes differing in trophic status and humic content. Microb Ecol 40:104-113

Lovejoy C, Carmack EC, Legendre L, Price NM (2002) Water column interleaving: a new physical mechanism determining protist communities and bacterial states. Limnol Oceanogr 47:1819-1831

Massana R, Murray AE, Preston CM, DeLong EF (1997) Vertical distribution and phylogenetic characterization of marine planktonic Archaea in the Santa Barbara Channel. Appl Environ Microbiol 63:50-56

Mullins TD, Britschgi TB, Krest RL, Giovannoni SJ (1995) Genetic comparisons reveal the same unknown bacterial lineages in Atlantic and Pacific bacterioplankton communities. Limnol Oceanogr 40:148-158

Murray AE, Hollibaugh JT, Orrego C (1996) Phylogenetic composition of bacterioplankton fromtwo California estuaries compared by denaturing gradient gel electrophoresis of $16 \mathrm{~S}$ rDNA fragments. Appl Environ Microbiol 62: 2676-2680

Murray AE, Preston CM, Massana R, Taylor LT, Blakis A, Wu K, DeLong EF (1998) Seasonal and spatial variability of bacterial and archaeal assemblages in the coastal waters near Anvers Island, Antarctica. Appl Environ Microbiol 64:2585-2595

Murray AE, Wu KY, Moyer CL, Karl DM, Delong EF (1999) Evidence for circumpolar distribution of planktonic Archaea in the Southern Ocean. Aquat Microb Ecol 18: 263-273

Pernthaler A, Pernthaler J, Eilers H, Amann R (2001) Growth patterns of two marine isolates: adaptations to substrate patchiness. Appl Environ Microbiol 67:4077-4083

Pernthaler A, Pernthaler J, Amann R (2002) Fluorescence in situ hybridization and catalyzed reporter deposition for the identification of marine bacteria. Appl Environ Microbiol 68:3094-3101

Pinhassi J, Berman T (2003) Differential growth response of colony-forming $\alpha$ - and $\gamma$-Proteobacteria in dilution culture and nutrient addition experiments from Lake Kinneret (Israel), the eastern Mediterranean Sea, and the Gulf of Eilat. Appl Environ Microbiol 63:199-211

Pinhassi J, Hagström Å (2000) Seasonal succession in marine bacterioplankton. Aquat Microb Ecol 21:245-256

Pinhassi J, Zweifel UL, Hagström Å (1997) Dominant marine bacterioplankton species found among colony-forming bacteria. Appl Environ Microbiol 63:3359-3366

Pinhassi J, Azam F, Hemphälä J, Long RA, Martinez J, Zweifel UL, Hagström Å (1999) Coupling between bacterioplankton species composition, population dynamics, and organic matter degradation. Aquat Microb Ecol 17: $13-26$

Platt T, Rao DVS, Irvin B (1983) Photosynthesis of picoplankton in the oligotrophic ocean. Nature 301:702-704

Porter KG, Feig YS (1980) The use of DAPI for identifying and counting aquatic microflora. Limnol Oceanogr 25:943-948 
Richardson K (1985) Plankton distribution and activity in the North Sea/Skagerrak-Kattegat frontal area in April 1984. Mar Ecol Prog Ser 26:233-244

Riemann L, Middelboe M (2002) Stability of bacterial and viral community compositions in Danish coastal waters as depicted by DNA fingerprinting techniques. Aquat Microb Ecol 27:219-232

Riemann L, Steward GF, Fandino LB, Campbell L, Landry MR, Azam F (1999) Bacterial community composition during 2 consecutive NE monsoon periods in the Arabian Sea studied by denaturing gradient gel electrophoresis (DGGE). Deep Sea Res II 46:1791-1811

Ryther J (1969) Photosynthesis and fish production in the sea: the production of organic matter and its conversion to higher forms of life throughout the world ocean. Science 166:72-76

Sala MM, Peters F, Gasol JM, Pedrós-Alió C, Marrasé C, Vaqué D (2002) Seasonal and spatial variations in the nutrient limitation of bacterioplankton growth in the northwestern Mediterranean. Aquat Microb Ecol 27: 47-56

Schäfer H, Abbas B, Witte H, Muyzer G (2002) Genetic diversity of 'satellite' bacteria present in cultures of marine diatoms. FEMS Microbiol Ecol 42:25-35

Schauer M, Massana R, Pedrós-Alió C (2000) Spatial differences in bacterioplankton composition along the Catalan coast (NW Mediterranean) assessed by molecular fingerprinting. FEMS Microbiol Ecol 33:51-59

Schlüter L, Havskum H (1997) Phytoplankton pigments in relation to carbon content in phytoplankton communities. Mar Ecol Prog Ser 155:55-65

Shiba T, Simidu U (1982) Erythrobacter longus gen. nov., sp.

Editorial responsibility: Otto Kinne (Editor),

Oldendorf/Luhe, Germany nov., an aerobic bacterium which contains bacteriochlorophyll a. Int J Syst Bacteriol 32:211-217

Smith DC, Azam F (1992) A simple, economical method for measuring bacterial protein synthesis rates in seawater using 3H-leucine. Mar Microb Food Webs 6:107-114

Suzuki MT, Preston CM, Chavez FP, DeLong EF (2001) Quantitative mapping of bacterioplankton populations in seawater: field tests across an upwelling plume in Monterey Bay. Aquat Microb Ecol 24:117-127

Vrede K, Heldal M, Norland S, Bratbak G (2002) Elemental composition $(\mathrm{C}, \mathrm{N}, \mathrm{P})$ and cell volume of exponentially growing and nutrient limited bacterioplankton. Appl Environ Microbiol 68:2965-2971

Weinbauer MG, Höfle MG (1998) Distribution and life strategies of two bacterial populations in a eutrophic lake. Appl Environ Microbiol 64:3776-3783

Weiner RM, Melick M, O'Neill K, Quintero E (2000) $\mathrm{Hy}$ phomonas adhaerens sp. nov., Hyphomonas johnsonii sp. nov. and Hyphomonas resenbergii sp. nov., marine budding and prosthecate bacteria. Int J Syst Evol Microbiol 50:459-469

Wright SW, Jeffrey SW, Mantoura RFC, Llewellyn CA, Bjørnland T, Repeta D, Welschmeyer N (1991) Improved HPLC method for the analysis of chlorophylls and carotenoids from marine phytoplankton. Mar Ecol Prog Ser 77: 183-196

ZoBell CE (1946) Marine microbiology: a monograph on hydrobacteriology. Cronica Botanica, Waltham, MA

Zubkov MV, Fuchs BM, Tarran GA, Burkill BH, Amann R (2002) Mesoscale distribution of dominant bacterioplankton groups in the northern North Sea in early summer. Aquat Microb Ecol 29:135-144

Submitted: December 16, 2002; Accepted: March 18, 2003

Proofs received from author(s): May 19, 2003 